\title{
Resistance to freezing and thawing of mortar specimens made from sulphoaluminate-belite cement
}

\author{
I JANOTKA* and L' KRAJÈI \\ Institute of Construction and Architecture of the Slovak Academy of Sciences, Bratislava, Slovak Republic
}

MS received 3 June 2000; revised 2 September 2000

\begin{abstract}
Resistance to freezing and thawing of mortar specimens made from sulphoaluminate-belite cement (M-SAB) is compared with that of mortars made from portland cement (M-PC). The results suggest that larger median radius of the pores and total porosity of M-SAB compared to those of M-PC are primarily caused by the rapid setting of the SAB cement. The 'coarsening' of pore structure of mortar specimens under action of freezing and thawing is proved by the increase in the macropores portion, median pore radius, and total porosity values. This process is more intense in M-SAB. The effect of the frost attack is confirmed by lower compressive strength and dynamic modulus of elasticity on the one hand and higher absorption capacity, expansion, and crack propagation of M-SAB compared with those of M-PC on the other hand. Besides the decreased frost resistance of M-SAB as compared with that of M-PC, unsatisfactory passivation of steel in M-SAB was found. The reason of this fact is the $\mathrm{pH}$ value decrease to less than 11.5 of the M-SAB extract.
\end{abstract}

Keywords. Frost resistance; low-energy sulphoaluminate-belite cement; steel reinforcement corrosion.

\section{Introduction}

Portland cement (PC) production is markedly dependent on a relatively high thermal and electric energy consumption for firing and grinding of the clinker. Moreover, combustion of fossil fuels and decarbonation of limestone contribute to releasing up to $\sim 10^{9} \mathrm{t}$ carbon dioxide into atmosphere annually (Mehta 1978). To solve these problems new alternative types replacing portland cements are developed. From this viewpoint sulphoaluminatebelite cements $(\mathrm{SAB})$ represent one of the suitable and interesting tendencies in cement industry. The highest progress in SAB cements has been done in China and the UK (Wang et al 1992; Brooks and Sharp 1990).

The composition of Portland cement clinker comprises four phases: alite $\left(C_{3} S\right)$, belite $\left(\beta-C_{2} S\right)$, aluminate $\left(C_{3} A\right)$, and ferrite $\left(\mathrm{C}_{4} \mathrm{AF}\right)$. Typical $\mathrm{PC}$ clinker contains about 60 $65 \%$ alite and $20-25 \%$ belite. In belite each mole of silica $\left(\mathrm{SiO}_{2}\right)$ is associated with two moles of lime $(\mathrm{CaO})$. Belite is formed at $200^{\circ} \mathrm{C}$ lower temperature than alite (formed above $1400^{\circ} \mathrm{C}$ ) and hence consumes less energy in its production than alite (Sahu and Majling 1994; Palou et al 1998). Calcium sulphoaluminate $\mathrm{C}_{4} \mathrm{~A}_{3} \overline{\mathrm{S}}$ often known as Klein's compound is readily synthesized along with belite and ferrite at about $1300^{\circ} \mathrm{C}$. The total theoretical heat requirement for $\mathrm{SAB}$ cement is $1337 \mathrm{~kJ} \cdot \mathrm{kg}^{-1}$ compared with $1756 \mathrm{~kJ} \cdot \mathrm{kg}^{-1}$ for PC (Janotka and Krajèi 1999). Enthalpy of formation for $\mathrm{C}_{3} \mathrm{~S}$ is $1848 \mathrm{~kJ} \cdot \mathrm{kg}^{-1}$ clinker, for

\footnotetext{
*Author for correspondence
}

$\beta-\mathrm{C}_{2} \mathrm{~S} 1336 \mathrm{~kJ} \cdot \mathrm{kg}^{-1}$ clinker, and that for $\mathrm{C}_{4} \mathrm{~A}_{3} \overline{\mathrm{S}}$ only around $800 \mathrm{~kJ} \cdot \mathrm{kg}^{-1}$ clinker. Carbon dioxide release during firing of $\mathrm{C}_{3} \mathrm{~S}$ is $0.578 \mathrm{~kg} \cdot \mathrm{kg}^{-1}$ clinker, of $\beta-\mathrm{C}_{2} \mathrm{~S}$ $0.511 \mathrm{~kg} \cdot \mathrm{kg}^{-1}$ clinker, and that of $\mathrm{C}_{4} \mathrm{~A}_{3} \overline{\mathrm{S}}$ is $0.216 \mathrm{~kg} \cdot \mathrm{kg}^{-1}$ clinker (Sharp 1998). These data show that cements based on belite and sulphoaluminate are of great advantage from the view point of energy savings and quantity of $\mathrm{CO}_{2}$ released during their production.

One productive approach to achieving a low energy cement is to incorporate a second reactive component along with belite. This component is $\mathrm{C}_{4} \mathrm{~A}_{3} \overline{\mathrm{S}}$ giving thus sulphoaluminate-belite cement (SAB). The major phases present in $\mathrm{SAB}$ cement are $\mathrm{C}_{2} \mathrm{~S}$ (usually below $30 \%$ ), $\mathrm{C}_{4} \mathrm{~A}_{3} \overline{\mathrm{S}}(40-70 \%)$, a ferrite solid solution (10-35\%), and gypsum $(\mathrm{C} \overline{\mathrm{S}})$. A reduction in limestone utilization of about $40 \%$ and energy savings of $25 \%$ appear to be possible with high $\mathrm{C}_{4} \mathrm{~A}_{3} \overline{\mathrm{S}}$ contents. $\mathrm{SAB}$ cements can be made using industrial waste materials, notably fly ashes and gypsum, providing additional environmental advantages. The clinker is relatively easy to grind, giving a further saving in energy consumption. If manufactured on a large scale, SAB cements should be relatively cheap (Lawrence 1995).

Besides fly ash and gypsum, red mud and blastfurnace slag instead of natural materials can also be used for SAB cement production (Drábik and Petroviè 1985; Havlica et al 1993; Sahu et al 1993; Sahu and Majling 1993; Ali et al 1994).

The continuing problem of SAB cement is very short setting up to $45 \mathrm{~min}$. Its durability under the attack of various media is still insufficiently verified (Beretka et al 
1993; Drábik et al 1996). Preliminary results show that SAB cement resistance to hydrochloric acid, sodium sulphate, and sodium chloride solutions is very similar to that of PC (Živica and Janotka 1996; Živica et al 1996).

Many serious causes of deterioration of concrete structures takes place under various environmental conditions. The action of frost belongs among the most significant. Concrete that is not resistant to freezing and thawing manifests two principal types of damage: internal cracking and surface scaling. Generally, freezing-thawing damage involves the expansion of cement paste generated by the $9 \%$ increase in volume as water is converted to ice inside a concrete element. Saturation of pores (91\%) is necessary in some capillary cavities before cement paste will expand and crack on freezing. Therefore, the porosity of cement paste plays an important role in determining the

Table 1. Chemical composition of raw materials for SAB cement preparation.

\begin{tabular}{lccc}
\hline Component & $\begin{array}{c}\text { Limestone } \\
(\%)\end{array}$ & $\begin{array}{c}\text { Fly ash } \\
(\%)\end{array}$ & $\begin{array}{c}\text { Gypsum } \\
(\%)\end{array}$ \\
\hline Moisture & $0 \cdot 10$ & $0 \cdot 35$ & 1.23 \\
Ignition loss $\left(1000^{\circ} \mathrm{C}\right)$ & $41 \cdot 70$ & $4 \cdot 11$ & 12.95 \\
$\mathrm{SiO}_{2}$ & $0 \cdot 10$ & $44 \cdot 24$ & - \\
$\mathrm{Al}_{2} \mathrm{O}_{3}$ & $1 \cdot 00$ & $42 \cdot 64$ & 5.98 \\
$\mathrm{Fe}_{2} \mathrm{O}_{3}$ & $0 \cdot 15$ & $4 \cdot 18$ & 1.89 \\
$\mathrm{CaO}$ & $55 \cdot 36$ & $2 \cdot 80$ & 25.84 \\
$\mathrm{MgO}$ & 1.40 & $0 \cdot 75$ & 0.63 \\
$\mathrm{SO}_{3}$ & - & - & 49.74 \\
$\mathrm{Na}_{2} \mathrm{O}$ & $0 \cdot 07$ & $0 \cdot 35$ & 0.62 \\
$\mathrm{~K}_{2} \mathrm{O}$ & $0 \cdot 03$ & $0 \cdot 52$ & 1.09 \\
\hline
\end{tabular}

frost resistance of concrete. The cement paste may be frost resistant if the amount of freezable water is not large and if the air void system is proper, e.g. bubble spacing factor is $0.2 \mathrm{~mm}$ or less (Mehta et al 1992).

The manufacture of relatively cheap cements that are environmentally acceptable both in their production and use is very important contribution for concrete world. However, a lower firing temperature of SAB cement relative to that of portland cement is responsible for the production of cement of lower class. This current imperfection of SAB cements might not be the reason for discouraging from the next serious investigation. Therefore, one would put effort to make possible improvements in basic properties of SAB cements, and important engineering properties of SAB cement-based materials.

Many authors dealt with the problem of how to produce concrete that is durable when subjected to cycles of freezing and thawing. However, their attention was drawn mainly on concrete made from portland cement modified either by various solids or plasticizing and air-entraining admixtures. The objective of this paper is to investigate the frost resistance of cement based materials made from more and more low-energy SAB cement used in the world.

\section{Experimental}

Ordinary portland cement and sulphoaluminate-belite cement were used in the experiment. Chemical composition of raw materials for $\mathrm{SAB}$ cement preparation is given in table 1. Chemical composition and properties of both cements are reported in table 2 .

Table 2. Composition and properties of the cements employed.

\begin{tabular}{|c|c|c|c|c|c|c|c|c|c|}
\hline $\begin{array}{l}\text { Component } \\
\text { content } \\
\text { (wt.\%) }\end{array}$ & $\begin{array}{l}\text { Ins. } \\
\text { res. }\end{array}$ & $\mathrm{SiO}_{2}$ & $\mathrm{CaO}$ & $\mathrm{Al}_{2} \mathrm{O}_{3}$ & $\mathrm{Fe}_{2} \mathrm{O}_{3}$ & $\mathrm{MgO}$ & $\mathrm{SO}_{3}$ & $\begin{array}{l}\text { Free } \\
\mathrm{CaO}\end{array}$ & $\begin{array}{l}\text { Ign. } \\
\text { loss }\end{array}$ \\
\hline $\mathrm{PC}$ & 0.74 & $20 \cdot 98$ & $63 \cdot 07$ & $5 \cdot 26$ & 3.79 & $2 \cdot 00$ & $2 \cdot 65$ & 0.40 & $1 \cdot 03$ \\
\hline SAB & $1 \cdot 35$ & $19 \cdot 69$ & $52 \cdot 58$ & $15 \cdot 45$ & $2 \cdot 60$ & $1 \cdot 50$ & $6 \cdot 12$ & 0 & $0 \cdot 48$ \\
\hline Cement & \multicolumn{5}{|c|}{$\begin{array}{l}\text { Specific gravity } \\
\left(\mathrm{kg} \cdot \mathrm{m}^{-3}\right)\end{array}$} & \multicolumn{4}{|c|}{$\begin{array}{l}\text { Specific surface area } \\
\left(\mathrm{m}^{2} \cdot \mathrm{kg}^{-1}\right) \text { Blaine }\end{array}$} \\
\hline $\mathrm{PC}$ & \multicolumn{5}{|c|}{3313} & \multicolumn{4}{|c|}{397.9} \\
\hline SAB & \multicolumn{5}{|c|}{3246} & \multicolumn{4}{|c|}{$381 \cdot 0$} \\
\hline \multicolumn{10}{|c|}{ Content (Bogue) (\%) } \\
\hline & & & $\mathrm{C}_{3} \mathrm{~S}$ & $\mathrm{C}_{2} \mathrm{~S}$ & $\mathrm{C}_{3} \mathrm{~A}$ & $\mathrm{C}_{4} \mathrm{~A}$ & $\mathrm{AF}$ & $\mathrm{CaSO}_{4}$ & \\
\hline \multirow[t]{2}{*}{$\mathrm{PC}$} & & & $56 \cdot 6$ & $17 \cdot 5$ & $7 \cdot 6$ & 11 . & $\cdot 5$ & $4 \cdot 5$ & \\
\hline & \multicolumn{5}{|c|}{ Initial set $(\mathrm{h} / \mathrm{min})$} & \multicolumn{4}{|c|}{ Final set (h/min) } \\
\hline \multirow{3}{*}{$\begin{array}{l}\text { PC } \\
\text { SAB }\end{array}$} & \multirow{2}{*}{\multicolumn{5}{|c|}{$\begin{array}{l}3 / 10 \\
0 / 10\end{array}$}} & \multirow{2}{*}{\multicolumn{4}{|c|}{$\begin{array}{l}5 / 05 \\
0 / 30\end{array}$}} \\
\hline & & & & & & & & & \\
\hline & \multicolumn{9}{|c|}{$\mathrm{pH}$ of cement extract } \\
\hline \multirow{2}{*}{$\begin{array}{l}\mathrm{PC} \\
\text { SAB }\end{array}$} & \multicolumn{9}{|c|}{$12 \cdot 55$} \\
\hline & & & & & $11 \cdot 84$ & & & & \\
\hline
\end{tabular}


The mortars with cement to quartz sand (Standard STN 721208$)$ ratio of $1: 3$ by mass and $w / c=0.6(\mathrm{w}=$ water, $\mathrm{c}=$ cement) were prepared. Fresh mixtures were compacted and moulded into $40 \times 40 \times 160 \mathrm{~mm}$ prisms. The specimens were stored for $24 \mathrm{~h}$ in the moist air ( $100 \%$ R.H.) at $20^{\circ} \mathrm{C}$ and then kept in water for 27 days at the ambient temperature. After this basic curing one group of mortar specimens was still maintained under water and the second was subjected to freezing and thawing cycling (FTC). One cycle involved $6 \mathrm{~h}$ in water at $+20^{\circ} \mathrm{C}$ and $18 \mathrm{~h}$ curing at $-40^{\circ} \mathrm{C}$. The specimens were exposed to frost during weekends. A Liebherr freezer from Austria was used for these tests. Visual observations of tested mortars were made periodically.

Mortar specimens were tested on dynamic modulus of elasticity (DME), flexural and compressive strength, and absorption capacity (AC). The test for AC was based on the difference in mass of the specimen saturated by water and dried at $105^{\circ} \mathrm{C}$. The decrease in mass is calculated as $\%$ loss in mass.

Expansion of mortar specimens was measured by using a dilatometer apparatus with dial gauge. The gauge length was $100 \mathrm{~mm}$ with measuring accuracy of $0.001 \mathrm{~mm}$. Changes in length were expressed in per mille.

Table 3. Clinker minerals in studied cements found by X-ray analysis.

\begin{tabular}{lll}
\hline & \multicolumn{2}{c}{ Clinker minerals } \\
\cline { 2 - 3 } Cement & \multicolumn{1}{c}{ Major } & \multicolumn{1}{c}{ Minor } \\
\hline PC & $\mathrm{C}_{3} \mathrm{~S}, \beta-\mathrm{C}_{2} \mathrm{~S}$ & $\mathrm{C}_{3} \mathrm{~A}, \mathrm{C}_{4} \mathrm{AF}$ \\
SAB & $\mathrm{C}_{4} \mathrm{~A}_{3} \mathrm{~S}, \beta-\mathrm{C}_{2} \mathrm{~S}$ & $\mathrm{C}_{4} \mathrm{AF}$ \\
\hline
\end{tabular}

Table 4. Strength and AC of mortars cured for 28 days in water.

\begin{tabular}{lccc}
\hline & \multicolumn{2}{c}{ Strength (MPa) } & \\
\cline { 2 - 3 } Mortar specimen & Flexural & Compressive & (wt.\%) \\
\hline M-PC & $7 \cdot 9$ & $43 \cdot 1$ & $10 \cdot 4$ \\
M-SAB & $3 \cdot 9$ & 22.5 & $11 \cdot 5$ \\
\hline
\end{tabular}

Table 5. Strength and AC of mortars at the time of FTC stopping.

\begin{tabular}{llccc}
\hline \multirow{2}{*}{$\begin{array}{l}\text { Mortar } \\
\text { specimen }\end{array}$} & Curing & Flexural & Compressive & AC \\
\cline { 3 - 4 } (wt.\%) \\
\hline \multirow{2}{*}{ M-PC } & Water & $9 \cdot 1$ & $54 \cdot 2$ & 9.5 \\
& FTC & $1 \cdot 1$ & $28 \cdot 2$ & 11.2 \\
& & & & \\
M-SAB & Water & 4.5 & $24 \cdot 0$ & 11.4 \\
& FTC & 0.2 & 6.3 & $15 \cdot 2$ \\
\hline
\end{tabular}

Pore structure of mortar specimens was studied by means of a high pressure mercury porosimeter model 2000 and macroporosimetry unit model 120 (both made by Erba Science in Milan, Italy). This apparatus enables estimation of pore radius between $3.75 \mathrm{~nm}$ and $0.2 \mathrm{~mm}$.

The ability of mortars to protect steel was found by the potentiodynamic method (Standard STN 73 1341) in mortar extracts. The mortar extract was prepared according to above-mentioned standard as follows: the mortar specimens were crushed, ground (size of particles $<0.2 \mathrm{~mm}$ ) and then mixed with distilled water (ratio $1: 4$ ). The prepared suspension was agitated for $6 \mathrm{~h}$ at the shaking machine. The water extract of mortar was obtained after filtration. The $\mathrm{pH}$ values of the extracts were estimated as well. For corrosion measurements reinforcing bars with diameter of $6 \mathrm{~mm}$ were used. Potentiodynamic curves of steel were obtained using Potentiostat OH-405 (Radelkis in Budapest, Hungary) under polarization rate $30 \mathrm{mV} \cdot \mathrm{min}^{-1}$.

\section{Results and discussion}

Significant differences in chemical and phase composition, initial and final set between PC and SAB cement are shown in tables 2 and 3 .

Flexural and compressive strengths of the mortar made from PC (M-PC) are higher than those of the mortar made from $\mathrm{SAB}$ cement $(\mathrm{M}-\mathrm{SAB})$. However, the value

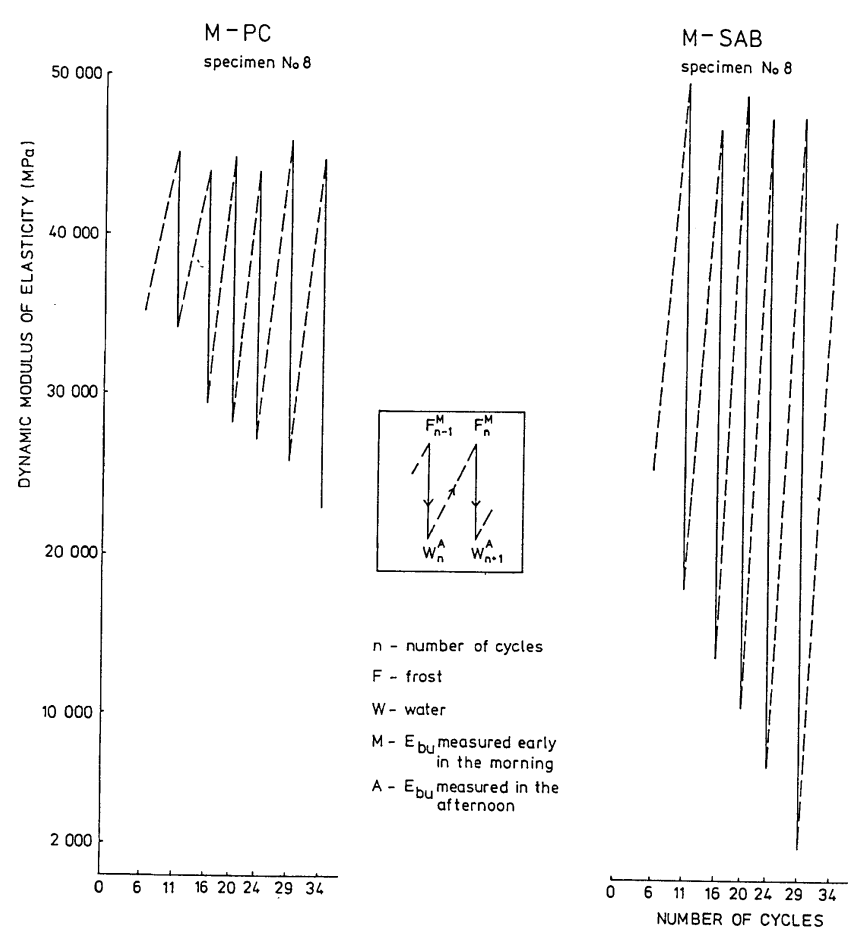

Figure 1. Decrease in DME of mortar specimens subjected to FTC. 
of $\mathrm{AC}$ in $\mathrm{M}-\mathrm{SAB}$ is partly higher in contrast to that of M-PC (table 4). Under FTC the decrease in compressive strength of M-SAB is more conspicuous than in M-PC. The increase in $\mathrm{AC}$ is evidently more considerable in M-SAB than in the M-PC (table 5). Under FTC the decrease in DME (figure 1) and increase in expansion (figure 2) are more pronounced in M-SAB than in M-PC. The FTC was stopped after 34 cycles when DME
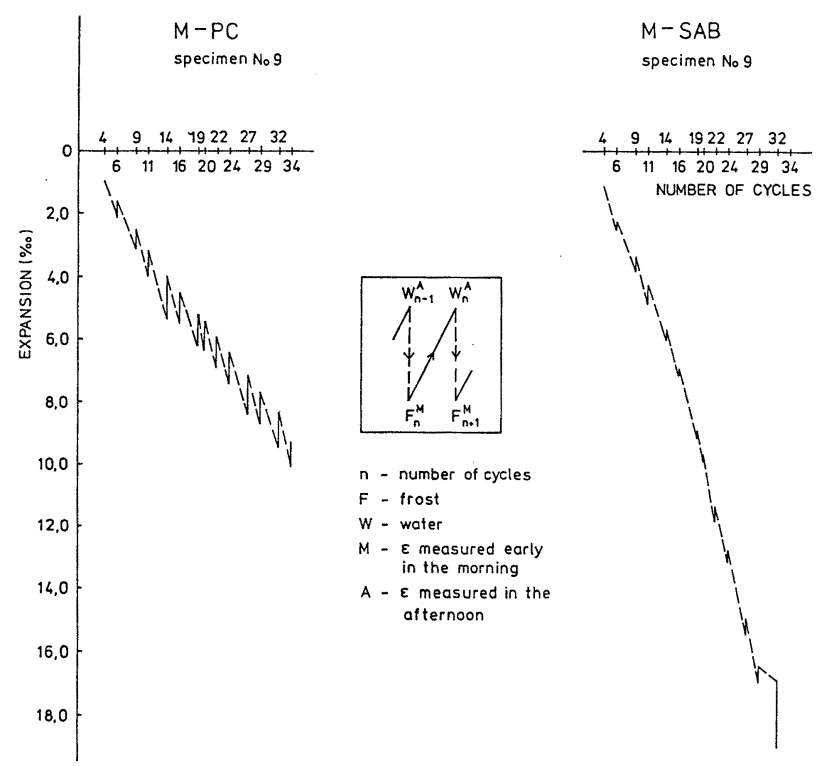

Figure 2. Increase in expansion of mortar specimens subjected to FTC. decrease of M-SAB achieved 5\% of the starting DME value. This value represents $29.2 \mathrm{GPa}$ for $\mathrm{M}-\mathrm{SAB}$ and $38.7 \mathrm{GPa}$ for M-PC. When FTC was stopping, crack propagation was observed on the surface of M-SAB specimens (figure 3). By contrast a negligible crack propagation was found in M-PC specimens (figure 4). The frost resistance of $\mathrm{M}-\mathrm{SAB}$ is lower than that of M-PC.

Table 6 shows the 'coarsening' of pore structure of the mortar specimens under FTC proved by the increase in macropores portion, median pore radius, and total porosity values. Significant differences in cumulative pore volume and pore radius distribution in $\mathrm{M}-\mathrm{PC}$ and $\mathrm{M}-$ $\mathrm{SAB}$ are shown in figure 5. A larger pore volume with radius less than $800 \mathrm{~nm}$ was observed in M-PC opposite to $\mathrm{M}-\mathrm{SAB}$. This dependence is converse over pore radius values of $800 \mathrm{~nm}$. The micropore radius distribution in tested mortars is decisively influenced by the used cement (coherence in course of curves 1 and 2 or 3 and 4 up to $800 \mathrm{~nm}$ and to a less extent in interval $800 \mathrm{~nm}-\mathrm{cca}$ $5000 \mathrm{~nm}$ of pore radii). The effect of frost is distinctly manifested in the range of macropores when pore radius is over $7500 \mathrm{~nm}$.

It is supposed that larger median pore radius and total porosity values in $\mathrm{M}-\mathrm{SAB}$ in contrast to $\mathrm{M}-\mathrm{PC}$ are primarily caused by rapid setting of the SAB cement. The process of periodical freezing and thawing is more conspicuous in $\mathrm{M}-\mathrm{SAB}$ with coarser pore structure than that developed in M-PC. The effect of the frost attack is confirmed by compressive strength and DME and higher AC of M-SAB opposite to M-PC subjected to FTC.

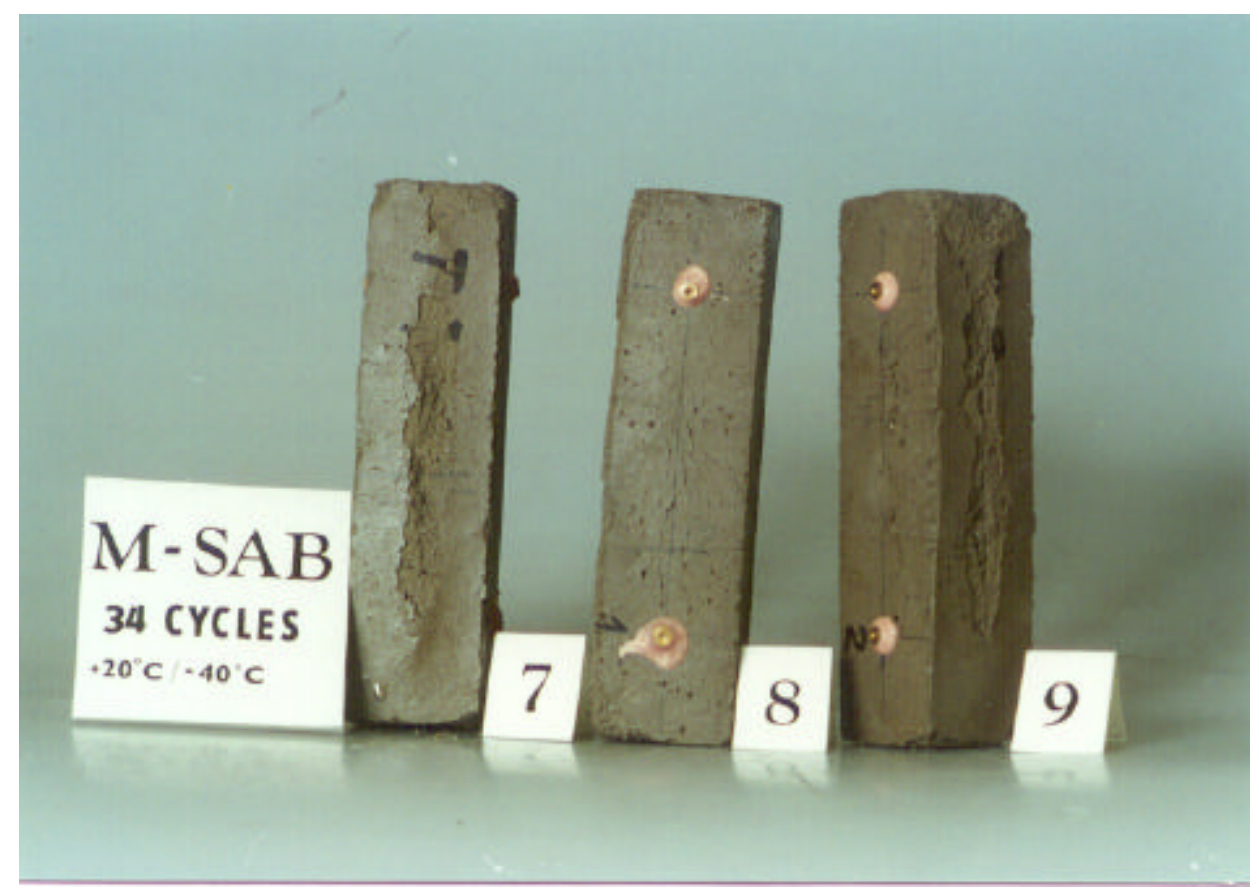

Figure 3. Surface damage of M-SAB mortar specimens subjected to FTC. 
Table 6. Pore structure study of tested mortars.

\begin{tabular}{lllccc}
\hline & & \multicolumn{2}{c}{ Portion } & & \\
\cline { 3 - 4 } $\begin{array}{l}\text { Mortar } \\
\text { specimen }\end{array}$ & Curing & $\begin{array}{c}\text { Micropores } \\
<7500 \mathrm{~nm} \\
(\%)\end{array}$ & $\begin{array}{c}\text { Macropores } \\
>7500 \mathrm{~nm} \\
(\%)\end{array}$ & $\begin{array}{c}\text { Median } \\
\text { pore } \\
\text { radius } \\
(\mathrm{nm})\end{array}$ & $\begin{array}{c}\text { Total } \\
\text { porosity } \\
(\%)\end{array}$ \\
\hline \multirow{2}{*}{ M-PC } & Water & 88.7 & $11 \cdot 3$ & $55 \cdot 3$ & $10 \cdot 8$ \\
& FTC & 79.7 & $20 \cdot 3$ & 184.9 & 14.7 \\
& Water & 96.7 & 3.3 & 808.3 & $17 \cdot 3$ \\
M-SAB & FTC & 85.4 & 14.6 & 1015.9 & 20.2 \\
\hline
\end{tabular}

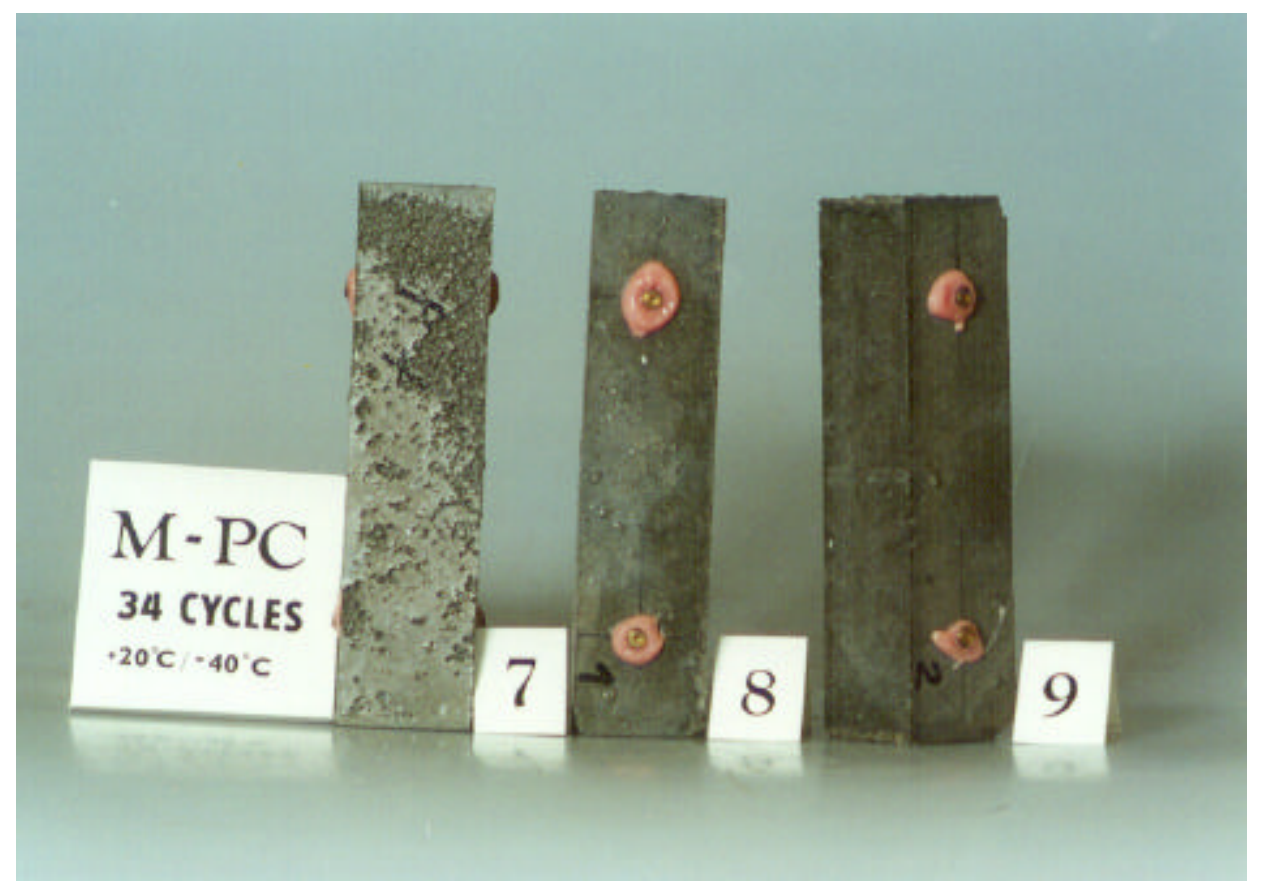

Figure 4. Surface damage of M-PC mortar specimens subjected to FTC.

The course of potentiodynamic curves of steel in $\mathrm{M}-$ $\mathrm{SAB}$ and $\mathrm{M}-\mathrm{PC}$ extract (figure 6) as well as related values of basic reinforcement characteristics (table 7) indicate electrochemical state of steel. The passive zone is a part of the potentio-dynamic curve with practically constant current density (figure 6). The presence of the protective oxide film on the steel surface is confirmed by the passive zone on the curve. However, the narrowing of the passive zone of steel in M-SAB extracts (figure 6) is the significant manifestation of the fact that steel is in non-stable passive state. The important electrochemical characteristic of steel-potential of breakdown-have dropped on values of 390 and $400 \mathrm{mV}$, respectively (table 7). Besides it is well known that $\gamma-\mathrm{Fe}_{2} \mathrm{O}_{3}$ protective oxide film on the steel surface starts to decompose below $\mathrm{pH}$ value of 11.5 (Gouda 1970) and subsequently steel is not fully passivated. Therefore, the worse ability of M-SAB to protect the steel against corrosion is caused by the $\mathrm{pH}$

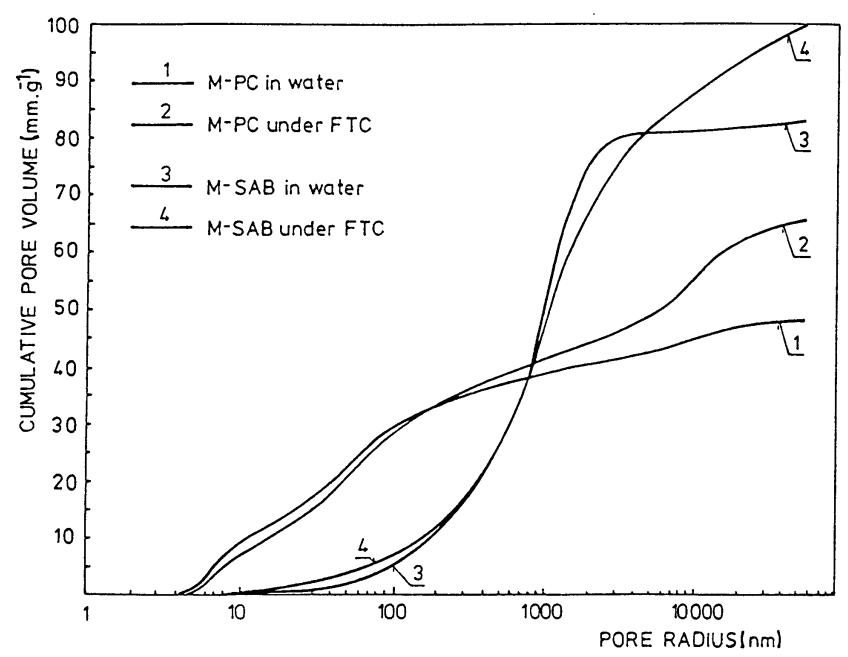

Figure 5. Cumulative pore volume versus pore radius in tested mortars. 
Table 7. Test results of steel reinforcement corrosion of tested mortars.

\begin{tabular}{|c|c|c|c|c|c|c|}
\hline $\begin{array}{l}\text { Mortar } \\
\text { specimen }\end{array}$ & Curing & $\begin{array}{l}\text { Stationary } \\
\text { potential } \\
(\mathrm{mV})\end{array}$ & $\begin{array}{l}\text { Current density } \\
\text { of passivation } \\
\left(\mathrm{A} \cdot \mathrm{m}^{-2}\right)\end{array}$ & $\begin{array}{l}\text { Potential of } \\
\text { breakdown } \\
\quad(\mathrm{mV})\end{array}$ & $\begin{array}{l}\text { State of } \\
\text { steel }\end{array}$ & $\begin{array}{l}\mathrm{pH} \text { of } \\
\text { extract }\end{array}$ \\
\hline \multirow{2}{*}{$\mathrm{M}-\mathrm{PC}$} & Water & -345 & 0.031 & 560 & Passive & $12 \cdot 37$ \\
\hline & FTC & -340 & 0.038 & 540 & Passive & $12 \cdot 33$ \\
\hline \multirow{2}{*}{ M-SAB } & Water & -340 & $0 \cdot 030$ & 400 & $\begin{array}{l}\text { Non-stable- } \\
\text { passive }\end{array}$ & $11 \cdot 25$ \\
\hline & FTC & -345 & $0 \cdot 036$ & 390 & $\begin{array}{l}\text { Non-stable- } \\
\text { passive }\end{array}$ & $11 \cdot 23$ \\
\hline
\end{tabular}

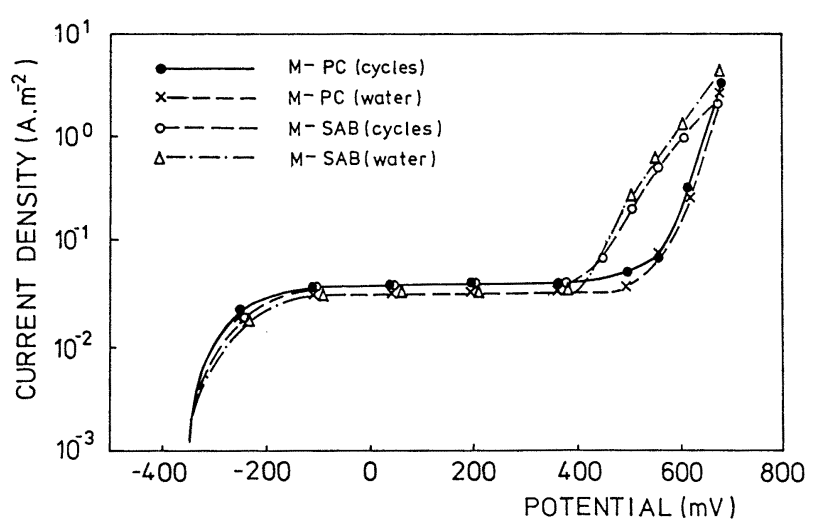

Figure 6. Potentiodynamic curves of steel immersed into $\mathrm{M}-\mathrm{SAB}$ and $\mathrm{M}-\mathrm{PC}$ extracts.

values decrease of its extract $(11.23 ; 11.25)$ compared with that of M-PC extract $(12 \cdot 33 ; 12 \cdot 37)$.

\section{Conclusions}

(I) Rapid initial set and different phase composition of SAB cement relative to those of portland cement contribute to the pore structure formation characterized by the extremely higher median pore radius and total porosity of M-SAB opposite to M-PC cured in water. These differences are more explicit at FTC. Higher drop in dynamic modulus of elasticity and compressive strength values as well as the increase in absorption capacity caused this.

(II) A more permeable pore system of $\mathrm{M}-\mathrm{SAB}$ enables faster transfer of the larger volume of water throughout $\mathrm{SAB}$ cement mortars relative to those of M-PC. A growth of formed ice crystals is then the source of internal expansive stresses which are responsible for mortar deterioration.

(III) It is important to slow down the set of SAB cement by changes in raw meal and firing condition to produce cement of higher quality.

(IV) The primary reason of worsened ability of M-SAB to protect the steel against corrosion is the $\mathrm{pH}$ value decrease to less than 11.5 of the mortar extract. It is necessary to provide increased alkalinity of SAB cement to avoid a danger of steel corrosion in SAB cement-based materials.

\section{Acknowledgement}

The authors are grateful to the Slovak Grant Agency for Science (Grant No. 2/7035/20) for support.

\section{References}

Ali M, Gopal S and Handoo S K 1994 Cem. Concr. Res. 24 715

Beretka J, Santoro L, Sherman N and Valenti G L 1993 Cem. Concr. Res. 231205

Brooks S A and Sharp J H 1990 Ettringite-based cements, calcium aluminate cements (eds) R I Mangabhai and F N Spon (London) p. 335

Drá bik M and Petroviè J 1985 Siliká ty 29227

Drá bik M, Gáliková L and Slade R T C 1996Proceedings of MAETA workshop on high flexural polymer cement composite (eds) N Maeda (Sakata: Maeta Concrete Industry Ltd) p. 107

Gouda V K 1970 Br. Corros. J. 5198

Havlica J, Roztocká D and Sahu S 1993 Cem. Concr. Res. 23 294

Janotka I and Krajèi L' 1999 Adv. Cem. Res. 1134

Lawrence C D 1995 COPERNICUS Program Report CIPA-CT 94-0105 1-88

Majling J, Sahu S, Vlna M and Roy D M 1993 Cem. Concr. Res. 231351

Mehta P K 1978 World Cem. Tech. 144

Mehta P K, Schiessl P and Raupach M 1992 Proceedings of 9th international congress on the chemistry of cement (ed.) A K Mullick (New Delhi: National Council for Cement and Building Materials (NCB)) p. 571

Palou M T, Majling J, Janotka I, Dan E and Popescu D 1998 Ceramics $\mathbf{4 2} 105$

Sahu S and Majling J 1993 Cem. Concr. Res. 231331

Sahu S and Majling J 1994 Cem. Concr. Res. 241065 
Sahu S, Tomková V, Majling J and Havlica J 1993 Cem. Concr. Res. 23693

Sharp J H 1998 Proceedings of international conference on the cements for the future: Calcium sulfoaluminates (London, Great Britain: The Institute of Materials and Society of Chemical Industry) p. 1

STN 721208 Standard Testing Sands (in Czech)

STN 731341 Standard Corrosion Protection of Reinforcements Provided by the Properties of Concrete. Methods of Test (in Slovak)

Wang Y, Su M, Yang R and Lui B 1992 Proceedings of 9th international congress on the chemistry of cement (ed.) A K Mullick (New Delhi: National Council for Cement and Building Materials (NCB)) p. 454

Živica V and Janotka I 1996 Proceedings of Solid State Chemistry, Bratislava, Slovakia (ed.) L T Nagy (Bratislava: The Slovak Society of Industrial Chemistry) p. 171

Živic a V, Janotka I and Majling J 1996 Proceedings of the chemistry and microstructure of cement and concrete, Sheffield, UK (ed.) F P Glasser (London: The Institute of Materials) Session 5 